\begin{tabular}{l|l|l|l|l|}
$\begin{array}{l}\text { Journal of } \\
\text { Endocrinology }\end{array}$ & $\begin{array}{l}\text { C J L Harter, G S Kavanagh } \\
\text { et al. }\end{array}$ & $\begin{array}{l}\text { Kisspeptin, reproduction and } \\
\text { metabolism }\end{array}$ & $\mathbf{2 3 8 : 3}$ & R173-R183
\end{tabular}

REVIEW

\title{
The role of kisspeptin neurons in reproduction and metabolism
}

\author{
Campbell J L Harter*, Georgia S Kavanagh* and Jeremy T Smith \\ School of Human Sciences, The University of Western Australia, Perth, Western Australia, Australia \\ Correspondence should be addressed to J T Smith: jeremy.smith@uwa.edu.au \\ *(C J L Harter and G S Kavanagh contributed equally to this work)
}

\section{Abstract}

Kisspeptin is a neuropeptide with a critical role in the function of the hypothalamic-

$\begin{aligned} & \text { Key Words } \\ & \text { - Kiss } 1 \\ & \text { - hypothalamus } \\ & \text { - fertility } \\ & \text { - energy homeostasis } \\ & \text { - glucose metabolism }\end{aligned}$
pituitary-gonadal (HPG) axis. Kisspeptin is produced by two major populations of neurons located in the hypothalamus, the rostral periventricular region of the third ventricle (RP3V) and arcuate nucleus (ARC). These neurons project to and activate gonadotrophin-releasing hormone $(\mathrm{GnRH})$ neurons (acting via the kisspeptin receptor, Kiss1r) in the hypothalamus and stimulate the secretion of GnRH. Gonadal sex steroids stimulate kisspeptin neurons in the RP3V, but inhibit kisspeptin neurons in the ARC, which is the underlying mechanism for positive- and negative feedback respectively, and it is now commonly accepted that the ARC kisspeptin neurons act as the GnRH pulse generator. Due to kisspeptin's profound effect on the HPG axis, a focus of recent research has been on afferent inputs to kisspeptin neurons and one specific area of interest has been energy balance, which is thought to facilitate effects such as suppressing fertility in those with under- or severe over-nutrition. Alternatively, evidence is building for a direct role for kisspeptin in regulating energy balance and metabolism. Kiss1r-knockout (KO) mice exhibit increased adiposity and reduced energy expenditure. Although the mechanisms underlying these observations are currently unknown, Kiss1r is expressed in adipose tissue and potentially brown adipose tissue (BAT) and Kiss1rKO mice exhibit reduced energy expenditure. Recent studies are now looking at the effects of kisspeptin signalling on behaviour, with clinical evidence emerging of kisspeptin affecting sexual behaviour, further investigation of potential neuronal pathways are warranted.

\section{Discovery and distribution of kisspeptin neurons}

\section{Kisspeptin and kisspeptin neurons}

In humans, kisspeptin refers to a family of neuropeptides resulting from the cleavage of a 145 amino acid precursor peptide encoded by the KISS1 gene (Lee et al. 1996, Ohtaki et al. 2001). Kisspeptin is thought to be active predominantly as a 54 amino acid peptide, while in mice, it exists as 52 amino acids (Ohtaki et al. 2001, Terao et al. 2004). The first observation of kisspeptin's function occurred in melanoma cell lines, where it acted as a metastasis inhibitor and thus it was initially known as 'metastin' (Lee et al. 1996). In humans, kisspeptin was found to be expressed in cell populations within the placenta, and later in the testes, ovaries, pancreas and small intestine (Kotani et al. 2001, Muir et al. 2001, Ohtaki et al. 2001). Significantly, kisspeptin 
was discovered and mapped in the brain, expressed in the rodent hypothalamus, specifically within neurons predominantly located in the arcuate nucleus (ARC) and the anteroventral periventricular nucleus (AVPV) extending into the periventricular nucleus (PEN) (Gottsch et al. 2004) - now referred collectively as the rostral periventricular region of the third ventricle (RP3V) (de Croft et al. 2012). In humans, kisspeptin neurons are found in the infundibular nucleus and preoptic area (POA), which are analogous to the rodent ARC and RP3V respectively (Rometo et al. 2007).

\section{The kisspeptin receptor}

Several years after the initial discovery of kisspeptin, a G-protein-coupled receptor that binds to the peptide with strong affinity was discovered, initially known as GPR54 (Lee et al. 1999, Kotani et al. 2001, Muir et al. 2001, Ohtaki et al. 2001). Following the discovery of kisspeptin's importance in the reproductive axis, the kisspeptin receptor GPR54 has since come to be known as Kiss1r (Gottsch et al. 2009a). The Kiss1r receptor is expressed within the rodent hypothalamus predominantly in the POA (Lee et al. 1999, Herbison et al. 2010) - notably on the majority of gonadotrophin-releasing hormone (GnRH) neurons (Irwig et al. 2004, Han et al. 2005) - and also the ARC (Lee et al. 1999). Similar, data are apparent in monkeys (Shahab et al. 2005, Kim et al. 2009) and sheep (Smith et al. 2009, 2011). Outside of the hypothalamus, Kiss1r can be found consistently in the hippocampus (Lee et al. 1999, Kotani et al. 2001, Muir et al. 2001, Ohtaki et al. 2001, Herbison et al. 2010) and outside the brain in the anterior pituitary, pancreas, liver and adipose tissue (Kotani et al. 2001, Muir et al. 2001, Ohtaki et al. 2001).

\section{Kisspeptin is critical for reproduction}

\section{The neuroendocrine control of fertility}

The reproductive 'axis' depends on the dynamic interplay between neural and hormonal signals originating from three primary sources: the anterior hypothalamus, where GnRH is synthesised and secreted in pulses; the anterior pituitary, where GnRH pulses stimulate pituitary gonadotrophin (luteinising hormone (LH) and folliclestimulating hormone (FSH)) secretion; and the gonads, which respond to the trophic actions of gonadotrophins by secreting sex steroids and producing gametes (Clarke et al. 2011, Navarro \& Tena-Sempere 2011). In turn, these sex steroids 'feedback' to the GnRH neurons in the hypothalamus to regulate their activity (Smith 2013) collectively forming the hypothalamic-pituitary-gonadal (HPG) axis. Since the discovery and characterisation of GnRH neurons, the search for the required inter-neuronal pathway linking steroid hormone feedback mechanism to these neurons was a priority - because GnRH neurons lack the prerequisite steroid hormone receptors (Herbison \& Theodosis 1992) - in particular oestrogen receptor (ER)- $\alpha$, which is known to be necessary for oestrogen to exert negative and positive feedback. Moreover, the existence and characterisation of an extrinsic GnRH pulse generator was one of the neuroendocrine field's most polarising challenges.

Two studies, published almost simultaneously, showed that kisspeptin/Kiss1r signalling was a major stimulus for the secretion of GnRH and gonadotrophins (de Roux et al. 2003, Seminara et al. 2003). Kisspeptin also seems to have an important role in the onset of puberty. Puberty is a phenomenon that is triggered by increasing pulsatility of GnRH secretion from the hypothalamus. Moreover, hypogonadotrophic hypogonadism is a condition characterised by impaired pubertal development and infertility that occurs when the pulsatility of GnRH is insufficient or absent. The initial studies that discovered kisspeptin's reproductive importance by Seminara et al. (2003) and de Roux et al. (2003) observed consanguineous families that had members with idiopathic hypogonadotrophic hypogonadism. Seminara and colleagues analysed the genome of these families to determine a genetic contributor to this condition and discovered affected individuals were homozygous for a 'L148S' mutation in the GPR54 gene - Kiss1r. Seminara et al. (2003) also created a mouse model deficient in Kiss1r, and it was found that these mice expressed an identical phenotype of hypogonadotrophic hypogonadism, characterised by small testes in male mice, small ovaries in females as well as an absence of follicular maturation and a delay in vaginal opening. However, exogenous administration of GnRH to these mice reverted them back to a relatively normal phenotype, which suggested that kisspeptin acts by stimulating GnRH release (Seminara et al. 2003). From these findings, it was concluded that Kiss1r may be integral for the normal function of GnRH secretion and for puberty. Since it was known that the peptide from the Kiss1 gene (kisspeptin) had a strong affinity for this receptor, it was also suggested at this time that this peptide could be the stimulus for GnRH secretion. In addition to causing hypogonadotrophic hypogonadism, mutations in the Kiss1r gene also seem 
to be involved in precocious puberty: a condition in which the onset of puberty occurs much earlier than usual. Initial studies identified an autosomal dominant activating mutation in the Kiss1r gene in individuals with this condition (Teles et al. 2008).

After the initial evidence of kisspeptin's reproductive functions, many studies - primarily in rodents, but some in sheep, monkey and goat - allowed for the further expansion of knowledge of kisspeptin biology. Gottsch et al. (2004) examined the effects of direct kisspeptin administration to the lateral cerebral ventricle of the mouse brain. They found that both LH and FSH were stimulated by the presence of kisspeptin - even at doses as low as $1 \mathrm{fmol}$. Furthermore, administration of a GnRH antagonist (acyline) prevented kisspeptin's stimulatory effect, providing the first evidence that kisspeptin acts solely via GnRH neurons to stimulate gonadotrophin release (Gottsch et al. 2004). Further studies of GnRH neurons themselves revealed their affinity to kisspeptin peptide. Irwig et al. (2004) analysed GnRH neurons in male rats with immunocytochemical techniques and found that in response to exogenous kisspeptin treatment, $86 \%$ of the GnRH neurons coexpressed Fos (a marker of neuronal transcription and hence activation), as opposed to less than $1 \%$ of GnRH neurons activated in untreated controls. Furthermore, the authors used double-label in situ hybridization to determine the proportion of GnRH neurons that expressed Kiss $1 r$ mRNA. It was found that $77 \%$ of neurons did, suggesting the majority of GnRH neurons express the kisspeptin receptor, thus allowing direct activation of kisspeptin (Irwig et al. 2004).

The electrophysiological properties of GnRH neurons in response to kisspeptin were analysed in a study by Han et al. (2005). When looking in adult male and female mice, they observed a significant depolarisation of more than $90 \%$ of GnRH neurons following administration of kisspeptin, consistent with similar percentage of GnRH neurons that expressed Kiss1r mRNA (Han et al. 2005). In addition to this, juvenile (postnatal day 8-19) and pre-pubertal (postnatal day 26-33) mice treated with kisspeptin only experienced a depolarisation in $27 \%$ and $40 \%$ of GnRH neurons respectively, suggesting that the number of kisspeptin-responsive GnRH neurons increases over pubertal development.

\section{Characterisation of kisspeptin neurons}

Clarkson \& Herbison (2006) investigated the neuroanatomical arrangement and development of kisspeptin neurons using male and female mice.
They found that kisspeptin neuronal cell bodies existed primarily in the ARC and RP3V. They also noticed a sexual dimorphism in the number of kisspeptin neurons present in the RP3V, with females having drastically more than males (Clarkson \& Herbison 2006). Dual immunofluorescence revealed close appositions between kisspeptin fibres and GnRH cell bodies, which first appeared in pre-pubertal mice (postnatal day 25) and grew in number throughout further pubertal development (Clarkson \& Herbison 2006). Moreover, projections from kisspeptin neurons extend throughout midline/ periventricular hypothalamic areas and extending to the median preoptic nucleus (Clarkson et al. 2009). Recent CLARITY processing of Kiss1-CRE mouse brains confirmed this distribution and was able to conclude projections of kisspeptin terminals from both ARC and RP3V kisspeptin populations to preoptic areas. In addition, RP3V kisspeptin neurons project to the ARC and ARC kisspeptin neurons project to the RP3V, in addition to lateral hypothalamic regions (Yeo et al. 2016).

We further investigated the neuroanatomical arrangement of kisspeptin neurons and the effects they have on GnRH secretion. Looking in ewes, we found that kisspeptin treatment significantly stimulated GnRH secretion into the hypophyseal portal system (Smith et al. 2011), which travels directly to the anterior pituitary, allowing exquisite control over the release of gonadotrophins. Moreover, the GnRH neuron terminals in the median eminence are apposed to projections from kisspeptin neurons (Smith et al. 2011), establishing a novel 'axo-axonal' method of kisspeptin-GnRH control, where kisspeptin stimulates GnRH release (d'Anglemont de Tassigny et al. 2008, Smith et al. 2011, Uenoyama et al . 2011). Using immunohistochemical and neuro-tracing techniques, we followed these fibres to their origin, which was found to be the ARC. This further strengthened the theory of kisspeptin's integral role in the HPG axis.

\section{Effects of sex steroids on kisspeptin neurons}

It has long been known that oestrogens have both negative and positive feedback effects on GnRH secretion; however, the mechanisms through which a single hormone could change modes of feedback were not fully understood. Moreover, the neuroanatomical pathway in which this feedback was achieved was also unknown because the GnRH neurons in mammals do not express any of the requisite receptors (Herbison \& Theodosis 1992). Following the discovery of kisspeptin's critical reproductive role, the hypothesis arose that feedback 
effects could be mediated by kisspeptin neurons. Our studies looked at the expression of Kiss1 mRNA in both the ARC and RP3V in response to gonadal steroids (Smith et al. 2005a,b) and noted differential regulation in these regions, particularly oestradiol stimulation of RP3V kisspeptin neurons and inhibition of ARC kisspeptin neurons. Moreover, we found that at the time of the preovulatory LH surge Kiss1 mRNA expression increased in the RP3V but decreased in the ARC (Smith et al. 2006). This was preliminary evidence that kisspeptin neurons in the ARC mediate negative feedback, while those in the RP3V mediate positive feedback. The precise mechanism by which oestradiol, acting through ER $\alpha$, achieves both positive and negative feedback in kisspeptin neuron populations is perplexing but may relate to classical (for positive) and non-classical (for negative) receptor signalling (Gottsch et al. 2009b). Additionally, divergent epigenetic regulation of the Kiss1 promoter region between the ARC and AVPV appears to play a significant role (Tomikawa et al. 2012). Here, oestrogen acting through ER $\alpha$ induces histone acetylation of the Kiss1 promoter and enhanced gene expression in the AVPV - but deacetylation in the ARC (Tomikawa et al. 2012). On top of this, it is now clear that progesterone receptor is vital for the positive feedback-induced LH surge (Mittelman-Smith et al. 2017) particularly its expression on kisspeptin neurons (Stephens et al. 2015, Gal et al. 2016) and androgen receptor may play a modulating role (Walters et al. 2018). Also important is that although ER $\alpha$ signalling in RP3V kisspeptin neurons is vital for positive feedback, ER $\alpha$ signalling in ARC kisspeptin neurons is not a complete requirement for negative feedback, as indicated in mice with kisspeptin cell-specific deletion of $\mathrm{ER} \alpha$ (Dubois et al. 2015). In these mice, oestradiol treatment resulted in the expected lack of change in Kiss1 mRNA in the ARC, but surprisingly the negative feedback regulation of LH concentration remained (Dubois et al. 2015). This suggests the existence of redundant negative feedback pathway independent of kisspeptin signalling. In addition, positive feedback is more important in females due to it being the mechanism responsible for the preovulatory LH surge - which does not occur in males a fact that is reflected by females having a much greater number of kisspeptin neurons in the RP3V (Clarkson \& Herbison 2006, Kauffman et al. 2007). The role of kisspeptin in the male RP3V is still, to our knowledge, unresolved.

In the ARC kisspeptin neurons, it is now accepted that the negative feedback regulation by gonadal sex steroids enables these neurons to act as the long sought-after GnRH pulse generator (Fig. 1). Previous immunohistochemical data detailed the neural machinery, involving the co-expression of the neuropeptides neurokinin B (NKB) and dynorphin (Dyn) within ARC kisspeptin neurons and autosynaptic control of these 'KNDy' neurons (Goodman et al. 2007, Navarro et al. 2009, Lehman et al. 2010). The model stipulates that NKB acts on KNDy neurons to drive pulsatility and Dyn acts as the 'brake' halting pulses and kisspeptin is the final output to GnRH neurons. In mice and rats, communication within and between KNDy neurons exists because they express NKB and dynorphin receptors (Navarro et al. 2009) in addition to an ARC network of reciprocal projections (Burke et al. 2006, Clarkson et al. 2009) and possible cell-to-cell gap junction synchronisation (Ikegami et al. 2017). Pharmacological data in sheep support the KNDy hypothesis because central administration of NKB receptor antagonists reduces LH pulse frequency (Goodman et al. 2013, Li et al. 2015) and NKB or dynorphin receptor antagonists increase LH pulses (Goodman et al. 2013). Similar data are also apparent in goats, with electrophysiological multiple-unit activity recordings directed at KNDy neurons showing 'volleys' of activity consistent with GnRH pulse generator activity (Wakabayashi et al. 2010, 2013) and appropriate responses to kisspeptin and NKB receptor agonists (Yamamura et al. 2014, 2015). Despite this, recent data in sheep show persistent LH pulses in the presence of NKB receptor antagonists paired with a constant infusion of kisspeptin (Clarke et al. 2018), indicating KNDy neurons may not be the sole pulse generator in this species. Moreover, there is still debate and uncertainty as to how three neuropeptides are released from a single neuron with temporal specificity to interact and modulate secretion of a kisspeptin/GnRH pulse. Notwithstanding, new data show optogenetic control of ARC kisspeptin neurons and the generation of LH/GnRH pulses (Han et al. 2015), inhibition of pulses (Clarkson et al. 2017) and - more importantly - the resetting of ongoing pulsatility (Clarkson et al. 2017) providing the strongest evidence for ARC kisspeptin neurons as the hypothalamic GnRH pulse generator.

\section{Kisspeptin regulation of energy balance and metabolism}

\section{Effect of metabolism on fertility}

Reproduction is a resource-costly activity and as such its success is dependent on sufficient energy and nutrient reserves (Pasquali et al. 2007, Evans \& Anderson 2012). As a result, there is a well-established relationship between 


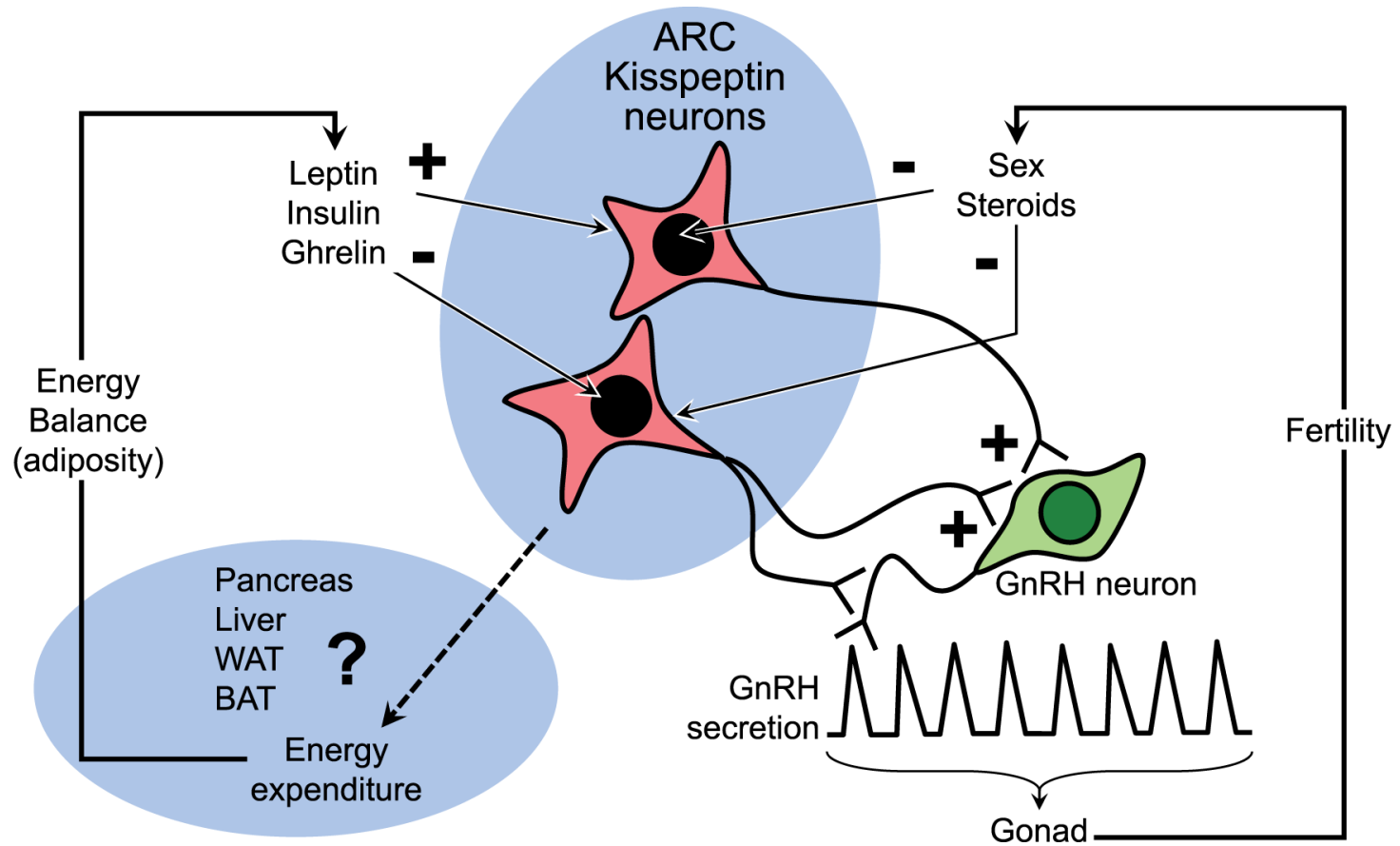

Figure 1

The potential function of kisspeptin neurons in mediating the relationship between energy balance and reproduction. Kisspeptin neurons in the arcuate nucleus (ARC) of the hypothalamus control reproduction through stimulation (+) of gonadotropin-releasing hormone (GnRH) neurons to regulate gonadal sex steroid production, which then has an inhibitory effect (-) on kisspeptin neurons. Kisspeptin neurons are also regulated by changes in energy balance. Levels of circulating metabolic hormones such as leptin, insulin and ghrelin are relayed onto kisspeptin neurons. Kisspeptin neurons also regulate energy expenditure and adipose tissue levels although the mechanisms underlying these observations are unknown.

metabolism and reproduction with states of altered energy balance associated with suppressed reproductive function. Luo et al. (2016) observed 72-h fasted female rats had decreased GnRH and Gnrh mRNA levels. Similar results were observed in food-restricted male rats (Compagnucci et al. 2002) and in mice (Castellano et al. 2005). Impaired fertility as a consequence of reduced food intake has also been reported in larger animal models; caloricrestricted ewes exhibited reduced LH concentration and reduced FSH secretion (Thomas et al. 1990). Humans with anorexia nervosa, a psychological condition resulting in persistent energy intake restriction, often have suppressed HPG axis activity - females with amenorrhoea, and males with reduced testosterone concentrations (Katz \& Vollenhoven 2000). These results indicate reproduction is sensitive to states of both short- and long-term negative energy balance.

Reproduction also appears to be sensitive to positive energy balance. Diet-induced obesity in rodents was coupled with reduced fertility and hypogonadism in males (Sanchez-Garrido et al. 2014). Similarly, diet-induced obesity in female mice impairs fertility by impacting systemic inflammation (Skaznik-Wikiel et al. 2016) but also by reducing hypothalamic Gnrh gene expression
(Tortoriello et al. 2004). With the increasing prevalence of overweight and obesity, it is not surprising that evidence is now emerging that positive energy balance also has a suppressive effect on reproduction in humans. Obesity in women is associated with alterations to negative feedback control of gonadotrophin secretion, increased risk of infertility and miscarriage and lower in vitro fertilisation success rates (Metwally et al. 2007). In males, obesity is known to reduce total testosterone levels and cause sexual dysfunction (Loret de Mola 2009).

\section{Effect of metabolism on hypothalamic kisspeptin}

Given the critical role that kisspeptin plays in governing the HPG axis, and its location within the ARC, it is not surprising that Kiss1 gene expression is also perturbed during periods of altered energy balance. Castellano et al. (2005) reported male and female pre-pubertal rats undergoing short-term under-nutrition had significantly reduced whole hypothalamic Kiss1 mRNA and increased hypothalamic Kiss1r mRNA compared to non-fasted littermates. LH response following central administration of kisspeptin was enhanced, indicating increased sensitivity, but lower output of kisspeptin during periods 
of negative energy balance. Conversely, the effect of overnutrition or increased adiposity on kisspeptin expression is not as well investigated. Quennell et al. (2011) reported female $o b / o b$ mice have reduced Kiss 1 mRNA in the ARC, but not the RP3V. Moreover, DBA/2J mice with dietinduced obesity had a marked decrease in Kiss1 mRNA in the RP3V and ARC, however, Dudek et al. (2016) did not observe any changes in whole hypothalamic Kiss 1 mRNA levels in obese mice but did show an increase in hypothalamic Kiss1r mRNA in mice with streptozotocininduced diabetes.

It is clear that kisspeptin neurons are sensitive to changes in metabolic status, but how this is mediated is contentious. Both NPY/AgRP and POMC/CART neurons in the ARC (our 'first order' orexigenic and anorexigenic neuronal populations respectively; Barsh \& Schwartz (2002) project to kisspeptin neurons in the ARC of sheep (Backholer et al. 2010, Padilla et al. 2017) and mice (Backholer et al. 2010, Padilla et al. 2017) allowing changes in metabolic status to be integrated into kisspeptinmediated control of reproduction. Additionally, several studies report kisspeptin neurons themselves are also sensitive to metabolic hormones, particularly insulin, leptin (Cravo et al. 2013, Qiu et al. 2011, 2015) and ghrelin (Frazao et al. 2014). However, the physiological relevance of these inputs to kisspeptin neurons, particularly in relation to the effect of leptin cues on the onset of puberty (Donato et al. 2011), and also insulin (Evans et al. 2014) have been debated. To this point, we would like to stress caution with interpretation of mouse models employing Cre-lox technology as negative phenotypic results could be explained by imperfect recombination efficacy. In addition, the data presented above are derived from sheep and mouse models using an array of techniques (immunohistochemistry, Cre-lox transgenics and electrophysiology) each with limitations potentially contributing to inconsistencies. In any case, we feel it is clear that Kiss1 mRNA expression and subsequent control of GnRH release is modulated by metabolic status; however, the precise mechanisms and exact neuronal pathway are still to be unequivocally confirmed (Fig. 1).

\section{Kisspeptin signalling regulates energy balance}

While most of the research so far has focused on the effect of energy balance on kisspeptin, kisspeptin signalling in turn has recently emerged as a regulator of energy balance. Indeed, it is not uncommon for neuroendocrine circuits to have reciprocal control over both reproduction and metabolism (Rosenbaum \& Leibel 1998).

\section{Disrupted energy balance in Kiss1r KO mice}

In our publication (Tolson et al. 2014), we were the first to report an altered metabolic phenotype in Kiss1r KO mice. Specifically, adult Kiss1r KO female mice had significantly increased body weights and adiposity (assessed using dual energy X-ray absorptiometry) (Fig. 2), impaired glucose regulation and reduced energy expenditure (measured using metabolic cages) from 10 weeks of age. The results from this study contradict that of an earlier one by Lapatto et al. (2007) who reported no significant changes in body weight in either Kiss1KO or Kiss1rKO mice at 9-12 weeks of age, compared to WT littermates. In our data, bodyweight changes in Kiss1rKO mice do not manifest until 8-9 weeks of age and were only apparent in females (Tolson et al. 2014) despite changes in adiposity in both sexes. Moreover, a follow-up study (Tolson et al. 2016) showed that although no body mass changes were evident, Kiss1rKO mice had significantly increased adiposity and decreased energy expenditure as early as
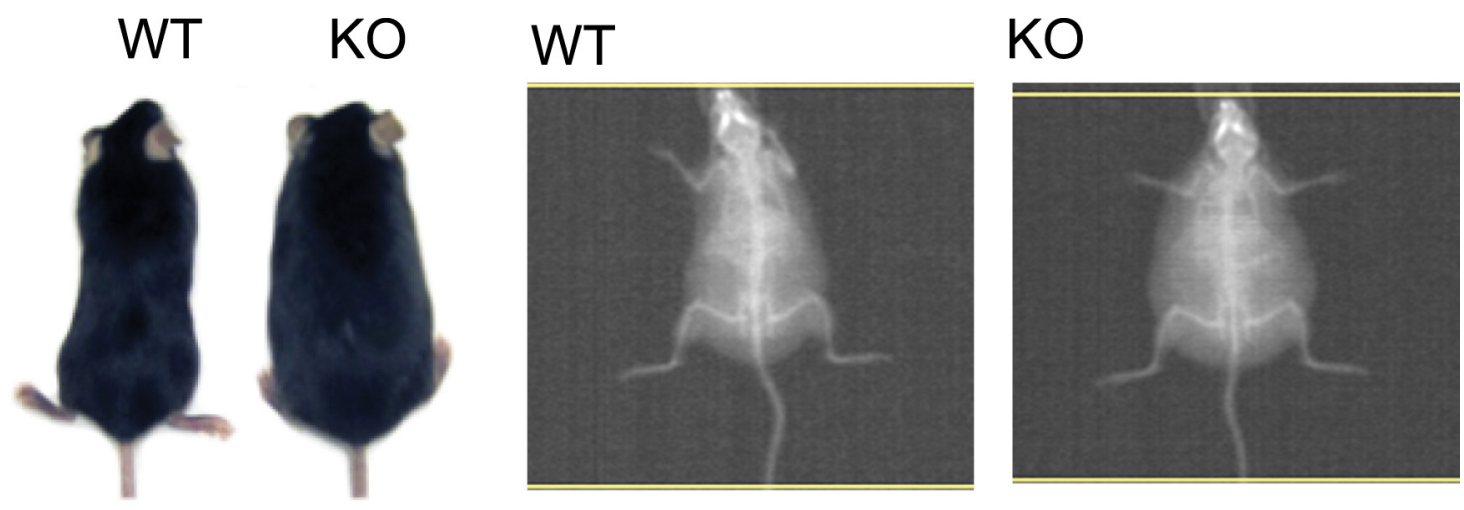

Figure 2

Obese phenotype in Kiss1rKO mice. Body weight phenotype comparison between female and WT and Kiss1rKO (KO) mice at 20 weeks of age. The obese phenotype of Kiss1rKO mice compared to WT is highlighted by dual energy X-ray absorptiometry imaging. 
6 weeks of age. These data suggest that the emergence of an obese phenotype in Kiss1rKO mice at maturity is likely to be a result of changes in metabolic function during early life, potentially even from birth. Our recent data confirmed the findings of Tolson and reported only female Kiss1rKO mice at maturity showed abnormal body weights and increased white adipose tissue mass suggesting that the altered metabolic phenotype in Kiss1r $\mathrm{KO}$ mice is sexually dimorphic, with females showing a greater phenotype than males (De Bond et al. 2016). Importantly, the increased adiposity was also evident in gonadectomised mice (males and females), suggesting the regulation of metabolism by kisspeptin neurons is not simply sex steroid dependent (Tolson et al. 2014) and due to some inherent characteristic of kisspeptin signalling.

\section{Action via NPY/AgRP and POMC/CART}

Kisspeptin appears able to directly innervate NPY/AgRP and POMC/CART neurons in a reciprocal manner, but the nature of these effects is subject to debate. In sheep, exogenous kisspeptin increased Npy mRNA expression and decreased Pomc mRNA (Backholer etal.2010). Alternatively, in mouse brain sections, electrophysiological recordings indicate an increase in activity of POMC neurons, and a decrease in NPY neurons, in response to kisspeptin treatment (Fu \& van den Pol 2010). This difference in response may indicate species differences (sheep versus mouse) or differences in experimental technique (in situ hybridisation versus electrophysiology), but they point to uncertainty surrounding the direct effect of kisspeptin on food intake neural circuitry. Thompson (Thompson et al. 2004) reported that ICV administration of kisspeptin in rats had no effect on food intake and similar data are apparent in sheep (Clarke et al. 2012). Unexpectedly, Kiss1rKO mice actually had reduced food intake, despite increased adiposity (Tolson et al. 2014, De Bond et al. 2016). We also reported gonadectomised Kiss1r KO mice showed no significant change in mRNA expression of Npy/Agrp or Pomc/Cart in the ARC compared to WT littermates (De Bond et al. 2016). These data potentially indicate the effects of kisspeptin signalling on energy balance are possibly the result of peripheral - rather than central - pathways.

\section{Action via peripheral tissue}

As hypothalamic regulators of appetite were found to not be the sole contributor to the altered metabolic phenotype in Kiss1rKO mice, the focus naturally shifts to peripheral kisspeptin signalling. Kiss1r is expressed in areas of the brain extending that of GnRH neuron control and also in the periphery, specifically the pancreas, liver and adipose tissue (Kotani et al. 2001). Kisspeptin has a proposed role in regulating the magnitude of the insulin response to glucose through a direct stimulatory effect on islet beta cells (Hauge-Evans et al. 2006). In the liver, glucagoninduced kisspeptin production inhibits insulin secretion in the mouse, with similar data determined in vitro with human pancreas - dependent on Kiss1r expression (Song et al. 2014), indicating kisspeptin may be pro-diabetic. What is confusing, however, is that kisspeptin appears to be capable of inhibiting or stimulating insulin secretion from islets (Hauge-Evans et al. 2006, Vikman \& Ahren 2009, Song et al. 2014). Nevertheless, it is doubtful these observations are sufficient to fully explain the altered metabolic phenotype in Kiss1rKO mice because adiposity, hyperleptinaemia and reduced energy expenditure all occur at 6 weeks of age (Tolson et al. 2016), while impairments in glucose tolerance present at older ages (18-20 weeks) and could potentially be a consequence of the obese state. Thus, despite initial investigations in the liver and pancreas, the importance of kisspeptin signalling in other peripheral tissues such as WAT and BAT, the latter known to regulate energy expenditure through thermogenesis (Napolitano \& Fawcett 1958, Saito et al. 2009) and possesses Kiss1r mRNA (Smith JT and Kauffman AS, unpublished observation), has not previously been reported and must be investigated (Fig. 1).

\section{Conclusions and future directions}

Despite a wealth of work highlighting the essential function of kisspeptin signalling in reproduction - specifically the control of GnRH neurons - little evidence exists regarding the potential regulatory role that kisspeptin signalling plays in controlling energy balance and metabolism. In particular, the mechanisms underlying the altered energy balance in the absence of kisspeptin signalling remains to be elucidated. There are clear links between circadian rhythms and kisspeptin signalling (Yap et al. 2016), and these may prove important in impairments in energy expenditure, which are more pronounced during the dark phase in Kiss1rKO mice (Tolson et al. 2014). Importantly, to our knowledge, there are no current reports of human obesity associated with KISS1 or KISS1R mutations. Nevertheless, there is recent evidence currently emerging of kisspeptin affecting behaviour, particularly human male sexual and emotional brain processing (Comninos et al. 2017). Female sexual behaviour in mice also appears to involve processing via 
kisspeptin neurons, potentially independent of Kiss1r (Hellier et al. 2018). Loss of kisspeptin signalling also appears to reduce anxiety-related behaviours in mice (Delmas et al. 2018). Another emerging effect of kisspeptin is the enhancement of memory capabilities in mice (Jiang et al. 2015). Despite these findings, the nature in which kisspeptin may bring about these limbic effects is not fully understood. It remains to be seen whether kisspeptin's role in these behavioural traits is directly linked to kisspeptin neural circuitry involved in governing energy balance, metabolism and predisposition to obesity.

\section{Declaration of interest}

The authors declare that there is no conflict of interest that could be perceived as prejudicing the impartiality of this review.

\section{Funding}

This work did not receive any specific grant from any funding agency in the public, commercial or not-for-profit sector.

\section{References}

Backholer K, Smith JT, Rao A, Pereira A, Iqbal J, Ogawa S, Li Q \& Clarke IJ 2010 Kisspeptin cells in the ewe brain respond to leptin and communicate with neuropeptide $\mathrm{Y}$ and proopiomelanocortin cells. Endocrinology 151 2233-2243. (https://doi.org/10.1210/en.2009-1190)

Barsh GS \& Schwartz MW 2002 Genetic approaches to studying energy balance: perception and integration. Nature Reviews Genetics $\mathbf{3}$ 589-600. (https://doi.org/10.1038/nrg862)

Burke MC, Letts PA, Krajewski SJ \& Rance NE 2006 Coexpression of dynorphin and neurokinin B immunoreactivity in the rat hypothalamus: morphologic evidence of interrelated function within the arcuate nucleus. Journal of Comparative Neurology 498 712-726. (https://doi.org/10.1002/cne.21086)

Castellano JM, Navarro VM, Fernandez-Fernandez R, Nogueiras R, Tovar S, Roa J, Vazquez MJ, Vigo E, Casanueva FF, Aguilar E, et al. 2005 Changes in hypothalamic KiSS-1 system and restoration of pubertal activation of the reproductive axis by kisspeptin in undernutrition. Endocrinology 146 3917-3925. (https://doi.org/10.1210/en.2005-0337)

Clarke IJ, Campbell R, Smith JT, Prevot V \& Wray S 2011 Neuroendocrine control of reproduction. In Handbook of Neuroendocrinology, pp 197-236. Eds G Fink, DW Pfaff \& JE Levine. London, UK: Academic Press.

Clarke IJ, Smith JT, Henry BA, Oldfield BJ, Stefanidis A, Millar RP, Sari IP, Chng K, Fabre-Nys C, Caraty A, et al. 2012 Gonadotropin-inhibitory hormone is a hypothalamic peptide that provides a molecular switch between reproduction and feeding. Neuroendocrinology 95 305-316. (https://doi.org/10.1159/000332822)

Clarke IJ, Li Q, Henry BA \& Millar RP 2018 Continuous kisspeptin restores luteinizing hormone pulsatility following cessation by a neurokinin B antagonist in female sheep. Endocrinology 159 639-646. (https://doi.org/10.1210/en.2017-00737)

Clarkson J \& Herbison AE 2006 Postnatal development of kisspeptin neurons in mouse hypothalamus; sexual dimorphism and projections to gonadotropin-releasing hormone neurons. Endocrinology 147 5817-5825. (https://doi.org/10.1210/en.2006-0787)
Clarkson J, d'Anglemont de Tassigny X, Colledge WH, Caraty A \& Herbison AE 2009 Distribution of kisspeptin neurones in the adult female mouse brain. Journal of Neuroendocrinology 21 673-682. (https://doi.org/10.1111/j.1365-2826.2009.01892.x)

Clarkson J, Han SY, Piet R, McLennan T, Kane GM, Ng J, Porteous RW, Kim JS, Colledge WH, Iremonger KJ, et al. 2017 Definition of the hypothalamic GnRH pulse generator in mice. PNAS $\mathbf{1 1 4}$ E10216-E10223. (https://doi.org/10.1073/pnas.1713897114)

Comninos AN, Wall MB, Demetriou L, Shah AJ, Clarke SA, Narayanaswamy S, Nesbitt A, Izzi-Engbeaya C, Prague JK, Abbara A, et al. 2017 Kisspeptin modulates sexual and emotional brain processing in humans. Journal of Clinical Investigation 127 709-719. (https://doi.org/10.1172/JCI89519)

Compagnucci C, Compagnucci GE, Lomniczi A, Mohn C, Vacas I, Cebral E, Elverdin JC, Friedman S, Rettori V \& Boyer PM 2002 Effect of nutritional stress on the hypothalamo-pituitary-gonadal axis in the growing male rat. Neuroimmunomodulation 10 153-162. (https://doi. org/10.1159/000067177)

Cravo RM, Frazao R, Perello M, Osborne-Lawrence S, Williams KW, Zigman JM, Vianna C \& Elias CF 2013 Leptin signaling in kiss1 neurons arises after pubertal development. PLOS ONE 8 e58698. (https://doi.org/10.1371/journal.pone.0058698)

d'Anglemont de Tassigny X, Fagg LA, Carlton MB \& Colledge WH 2008 Kisspeptin can stimulate gonadotropin-releasing hormone (GnRH) release by a direct action at GnRH nerve terminals. Endocrinology 149 3926-3932. (https://doi.org/10.1210/en.2007-1487)

De Bond JP, Tolson KP, Nasamran C, Kauffman AS \& Smith JT 2016 Unaltered hypothalamic metabolic gene expression in Kiss1r knockout mice despite obesity and reduced energy expenditure. Journal of Neuroendocrinology 28. (https://doi.org/10.1111/jne.12430)

de Croft S, Piet R, Mayer C, Mai O, Boehm U \& Herbison AE 2012 Spontaneous kisspeptin neuron firing in the adult mouse reveals marked sex and brain region differences but no support for a direct role in negative feedback. Endocrinology 153 5384-5393. (https://doi. org/10.1210/en.2012-1616)

de Roux N, Genin E, Carel JC, Matsuda F, Chaussain JL \& Milgrom E 2003 Hypogonadotropic hypogonadism due to loss of function of the KiSS1-derived peptide receptor GPR54. PNAS 100 10972-10976. (https://doi.org/10.1073/pnas.1834399100)

Delmas S, Porteous R, Bergin DH \& Herbison AE 2018 Altered aspects of anxiety-related behavior in kisspeptin receptor-deleted male mice. Scientific Reports 8 2794. (https://doi.org/10.1038/s41598-01821042-4)

Donato J Jr, Cravo RM, Frazao R, Gautron L, Scott MM, Lachey J, Castro IA, Margatho LO, Lee S, Lee C, et al. 2011 Leptin's effect on puberty in mice is relayed by the ventral premammillary nucleus and does not require signaling in Kiss1 neurons. Journal of Clinical Investigation 121 355-368. (https://doi.org/10.1172/JCI45106)

Dubois SL, Acosta-Martinez M, DeJoseph MR, Wolfe A, Radovick S, Boehm U, Urban JH \& Levine JE 2015 Positive, but not negative feedback actions of estradiol in adult female mice require estrogen receptor alpha in kisspeptin neurons. Endocrinology 156 1111-1120. (https://doi.org/10.1210/en.2014-1851)

Dudek M, Kolodziejski PA, Pruszynska-Oszmalek E, Sassek M, Ziarniak K, Nowak KW \& Sliwowska JH 2016 Effects of high-fat diet-induced obesity and diabetes on Kiss1 and GPR54 expression in the hypothalamic-pituitary-gonadal (HPG) axis and peripheral organs (fat, pancreas and liver) in male rats. Neuropeptides 56 41-49. (https:// doi.org/10.1016/j.npep.2016.01.005)

Evans JJ \& Anderson GM 2012 Balancing ovulation and anovulation: integration of the reproductive and energy balance axes by neuropeptides. Human Reproduction Update 18 313-332. (https://doi. org/10.1093/humupd/dms004)

Evans MC, Rizwan M, Mayer C, Boehm U \& Anderson GM 2014 Evidence that insulin signalling in gonadotrophin-releasing hormone and kisspeptin neurones does not play an essential role in metabolic (c) 2018 Society for Endocrinology Published by Bioscientifica Ltd. Printed in Great Britain 
regulation of fertility in mice. Journal of Neuroendocrinology 26 468-479. (https://doi.org/10.1111/jne.12166)

Frazao R, Dungan Lemko HM, da Silva RP, Ratra DV, Lee CE, Williams KW, Zigman JM \& Elias CF 2014 Estradiol modulates Kiss1 neuronal response to ghrelin. American Journal of Physiology: Endocrinology and Metabolism 306 E606-E614. (https://doi. org/10.1152/ajpendo.00211.2013)

Fu LY \& van den Pol AN 2010 Kisspeptin directly excites anorexigenic proopiomelanocortin neurons but inhibits orexigenic neuropeptide Y cells by an indirect synaptic mechanism. Journal of Neuroscience $\mathbf{3 0}$ 10205-10219. (https://doi.org/10.1523/JNEUROSCI.2098-10.2010)

Gal A, Lin PC, Cacioppo JA, Hannon PR, Mahoney MM, Wolfe A, Fernandez-Valdivia R, Lydon JP, Elias CF \& Ko C 2016 Loss of fertility in the absence of progesterone receptor expression in kisspeptin neurons of female mice. PLOS ONE 11 e0159534. (https://doi. org/10.1371/journal.pone.0159534)

Goodman RL, Lehman MN, Smith JT, Coolen LM, de Oliveira CV, Jafarzadehshirazi MR, Pereira A, Iqbal J, Caraty A, Ciofi P, et al. 2007 Kisspeptin neurons in the arcuate nucleus of the ewe express both dynorphin A and neurokinin B. Endocrinology 148 5752-5760. (https://doi.org/10.1210/en.2007-0961)

Goodman RL, Hileman SM, Nestor CC, Porter KL, Connors JM, Hardy SL, Millar RP, Cernea M, Coolen LM \& Lehman MN 2013 Kisspeptin, neurokinin $\mathrm{B}$, and dynorphin act in the arcuate nucleus to control activity of the GnRH pulse generator in ewes. Endocrinology $\mathbf{1 5 4}$ 4259-4269. (https://doi.org/10.1210/en.2013-1331)

Gottsch ML, Cunningham MJ, Smith JT, Popa SM, Acohido BV Crowley WF, Seminara S, Clifton DK \& Steiner RA 2004 A role for kisspeptins in the regulation of gonadotropin secretion in the mouse. Endocrinology 145 4073-4077. (https://doi.org/10.1210/en.2004-0431)

Gottsch ML, Clifton DK \& Steiner RA 2009a From KISS1 to kisspeptins: an historical perspective and suggested nomenclature. Peptides $\mathbf{3 0}$ 4-9. (https://doi.org/10.1016/j.peptides.2008.06.016)

Gottsch ML, Navarro VM, Zhao Z, Glidewell-Kenney C, Weiss J, Jameson JL, Clifton DK, Levine JE \& Steiner RA 2009b Regulation of Kiss 1 and dynorphin gene expression in the murine brain by classical and nonclassical estrogen receptor pathways. Journal of Neuroscience 29 9390-9395. (https://doi.org/10.1523/JNEUROSCI.0763-09.2009)

Han SK, Gottsch ML, Lee KJ, Popa SM, Smith JT, Jakawich SK, Clifton DK, Steiner RA \& Herbison AE 2005 Activation of gonadotropin-releasing hormone neurons by kisspeptin as a neuroendocrine switch for the onset of puberty. Journal of Neuroscience 25 11349-11356. (https://doi org/10.1523/JNEUROSCI.3328-05.2005)

Han SY, McLennan T, Czieselsky K \& Herbison AE 2015 Selective optogenetic activation of arcuate kisspeptin neurons generates pulsatile luteinizing hormone secretion. PNAS 112 13109-13114. (https://doi.org/10.1073/pnas.1512243112)

Hauge-Evans AC, Richardson CC, Milne HM, Christie MR, Persaud SJ \& Jones PM 2006 A role for kisspeptin in islet function. Diabetologia 49 2131-2135. (https://doi.org/10.1007/s00125-006-0343-z)

Hellier V, Brock O, Candlish M, Desroziers E, Aoki M, Mayer C, Piet R, Herbison A, Colledge WH, Prevot V, et al. 2018 Female sexual behavior in mice is controlled by kisspeptin neurons. Nature Communications 9 400. (https://doi.org/10.1038/s41467-017-02797-2)

Herbison AE \& Theodosis DT 1992 Immunocytochemical identification of oestrogen receptors in preoptic neurones containing calcitonin gene-related peptide in the male and female rat. Neuroendocrinology 56 761-764. (https://doi.org/10.1159/000126304)

Herbison AE, de Tassigny X, Doran J \& Colledge WH 2010 Distribution and postnatal development of Gpr54 gene expression in mouse brain and gonadotropin-releasing hormone neurons. Endocrinology 151 312-321. (https://doi.org/10.1210/en.2009-0552)

Ikegami K, Minabe S, Ieda N, Goto T, Sugimoto A, Nakamura S, Inoue N, Oishi S, Maturana AD, Sanbo M, et al. 2017 Evidence of involvement of neurone-glia/neurone-neurone communications via gap junctions in synchronised activity of KNDy neurones. Journal of Neuroendocrinology 29. (https://doi.org/10.1111/jne.12480)

Irwig MS, Fraley GS, Smith JT, Acohido BV, Popa SM, Cunningham MJ, Gottsch ML, Clifton DK \& Steiner RA 2004 Kisspeptin activation of gonadotropin releasing hormone neurons and regulation of KiSS-1 mRNA in the male rat. Neuroendocrinology 80 264-272. (https://doi. org/10.1159/000083140)

Jiang JH, He Z, Peng YL, Jin WD, Wang Z, Han RW, Chang M \& Wang R 2015 Kisspeptin-13 enhances memory and mitigates memory impairment induced by Abeta1-42 in mice novel object and object location recognition tasks. Neurobiology of Learning and Memory 123 187-195. (https://doi.org/10.1016/j.nlm.2015.05.010)

Katz MG \& Vollenhoven B 2000 The reproductive endocrine consequences of anorexia nervosa. British Journal of Obstetrics and Gynaecology 107 707-713. (https://doi.org/10.1111/j.1471-0528.2000. tb13329.x)

Kauffman AS, Gottsch ML, Roa J, Byquist AC, Crown A, Clifton DK, Hoffman GE, Steiner RA \& Tena-Sempere M 2007 Sexual differentiation of Kiss1 gene expression in the brain of the rat. Endocrinology 148 1774-1783. (https://doi.org/10.1210/en.2006-1540)

Kim W, Jessen HM, Auger AP \& Terasawa E 2009 Postmenopausal increase in KiSS-1, GPR54, and luteinizing hormone releasing hormone (LHRH-1) mRNA in the basal hypothalamus of female rhesus monkeys. Peptides 30 103-110. (https://doi.org/10.1016/j. peptides.2008.06.005)

Kotani M, Detheux M, Vandenbogaerde A, Communi D, Vanderwinden JM, Le Poul E, Brezillon S, Tyldesley R, SuarezHuerta N, Vandeput F, et al. 2001 The metastasis suppressor gene KiSS-1 encodes kisspeptins, the natural ligands of the orphan $G$ protein-coupled receptor GPR54. Journal of Biological Chemistry 276 34631-34636. (https://doi.org/10.1074/jbc.M104847200)

Lapatto R, Pallais JC, Zhang D, Chan YM, Mahan A, Cerrato F, Le WW, Hoffman GE \& Seminara SB 2007 Kiss1-/- mice exhibit more variable hypogonadism than Gpr54-/- mice. Endocrinology 148 4927-4936. (https://doi.org/10.1210/en.2007-0078)

Lee JH, Miele ME, Hicks DJ, Phillips KK, Trent JM, Weissman BE \& Welch DR 1996 KiSS-1, a novel human malignant melanoma metastasis-suppressor gene. Journal of the National Cancer Institute $\mathbf{8 8}$ 1731-1737. (https://doi.org/10.1093/jnci/88.23.1731)

Lee DK, Nguyen T, O'Neill GP, Cheng R, Liu Y, Howard AD, Coulombe N, Tan CP, Tang-Nguyen AT, George SR, et al. 1999 Discovery of a receptor related to the galanin receptors. FEBS Letters 446 103-107. (https://doi.org/10.1016/S0014-5793(99)00009-5)

Lehman MN, Coolen LM \& Goodman RL 2010 Minireview: kisspeptin/ neurokinin B/dynorphin (KNDy) cells of the arcuate nucleus: a central node in the control of gonadotropin-releasing hormone secretion. Endocrinology 151 3479-3489. (https://doi.org/10.1210/en.2010-0022)

Li Q, Millar RP, Clarke IJ \& Smith JT 2015 Evidence that neurokinin B controls basal gonadotropin-releasing hormone secretion but is not critical for estrogen-positive feedback in sheep. Neuroendocrinology 101 161-174. (https://doi.org/10.1159/000377702)

Loret de Mola JR 2009 Obesity and its relationship to infertility in men and women. Obstetrics and Gynecology Clinics of North America 36 333-346, ix. (https://doi.org/10.1016/j.ogc.2009.03.002)

Luo Q, Li W, Li M, Zhang X \& Zhang H 2016 Leptin/leptinR-kisspeptin/ kiss1r-GnRH pathway reacting to regulate puberty onset during negative energy balance. Life Science 153 207-212. (https://doi. org/10.1016/j.lfs.2016.03.048)

Metwally M, Li TC \& Ledger WL 2007 The impact of obesity on female reproductive function. Obesity Reviews 8 515-523. (https://doi. org/10.1111/j.1467-789X.2007.00406.x)

Mittelman-Smith MA, Rudolph LM, Mohr MA \& Micevych PE 2017 Rodent models of non-classical progesterone action regulating ovulation. Frontiers in Endocrinology 8 165. (https://doi.org/10.3389/ fendo.2017.00165) http://joe.endocrinology-journals.org

https://doi.org/10.1530/JOE-18-0108
(C) 2018 Society for Endocrinology Published by Bioscientifica Ltd. Printed in Great Britain 
Muir AI, Chamberlain L, Elshourbagy NA, Michalovich D, Moore DJ, Calamari A, Szekeres PG, Sarau HM, Chambers JK, Murdock P, et al. 2001 AXOR12, a novel human G protein-coupled receptor, activated by the peptide KiSS-1. Journal of Biological Chemistry 276 28969-28975. (https://doi.org/10.1074/jbc.M102743200)

Napolitano L \& Fawcett D 1958 The fine structure of brown adipose tissue in the newborn mouse and rat. Journal of Biophysical and Biochemical Cytology 4 685-692. (https://doi.org/10.1083/ jcb.4.6.685)

Navarro VM \& Tena-Sempere M 2011 Neuroendocrine control by kisspeptins: role in metabolic regulation of fertility. Nature Reviews Endocrinology 8 40-53. (https://doi.org/10.1038/nrendo.2011.147)

Navarro VM, Gottsch ML, Chavkin C, Okamura H, Clifton DK \& Steiner RA 2009 Regulation of gonadotropin-releasing hormone secretion by kisspeptin/dynorphin/neurokinin B neurons in the arcuate nucleus of the mouse. Journal of Neuroscience 29 11859-11866. (https://doi.org/10.1523/JNEUROSCI.1569-09.2009)

Ohtaki T, Shintani Y, Honda S, Matsumoto H, Hori A, Kanehashi K, Terao Y, Kumano S, Takatsu Y, Masuda Y, et al. 2001 Metastasis suppressor gene KiSS-1 encodes peptide ligand of a G-protein-coupled receptor. Nature $\mathbf{4 1 1}$ 613-617. (https://doi.org/10.1038/35079135)

Padilla SL, Qiu J, Nestor CC, Zhang C, Smith AW, Whiddon BB, Ronnekleiv OK, Kelly MJ \& Palmiter RD 2017 AgRP to Kiss1 neuron signaling links nutritional state and fertility. PNAS 114 2413-2418. (https://doi.org/10.1073/pnas.1621065114)

Pasquali R, Patton L \& Gambineri A 2007 Obesity and infertility. Current Opinion in Endocrinology, Diabetes and Obesity 14 482-487. (https://doi. org/10.1097/MED.0b013e3282f1d6cb)

Qiu J, Fang Y, Bosch MA, Ronnekleiv OK \& Kelly MJ 2011 Guinea pig kisspeptin neurons are depolarized by leptin via activation of TRPC channels. Endocrinology 152 1503-1514. (https://doi.org/10.1210/ en.2010-1285)

Qiu X, Dao H, Wang M, Heston A, Garcia KM, Sangal A, Dowling AR, Faulkner LD, Molitor SC, Elias CF, et al. 2015 Insulin and leptin signaling interact in the mouse Kiss1 neuron during the peripubertal period. PLOS ONE 10 e0121974. (https://doi.org/10.1371/journal. pone.0121974)

Quennell JH, Howell CS, Roa J, Augustine RA, Grattan DR \& Anderson GM 2011 Leptin deficiency and diet-induced obesity reduce hypothalamic kisspeptin expression in mice. Endocrinology 152 1541-1550. (https://doi.org/10.1210/en.2010-1100)

Rometo AM, Krajewski SJ, Voytko ML \& Rance NE 2007 Hypertrophy and increased kisspeptin gene expression in the hypothalamic infundibular nucleus of postmenopausal women and ovariectomized monkeys. Journal of Clinical Endocrinology and Metabolism 92 2744-2750. (https://doi.org/10.1210/jc.2007-0553)

Rosenbaum M \& Leibel RL 1998 Leptin: a molecule integrating somatic energy stores, energy expenditure and fertility. Trends in Endocrinology and Metabolism 9 117-124. (https://doi.org/10.1016/S10432760(98)00028-9)

Saito M, Okamatsu-Ogura Y, Matsushita M, Watanabe K, Yoneshiro T, Nio-Kobayashi J, Iwanaga T, Miyagawa M, Kameya T, Nakada K, et al. 2009 High incidence of metabolically active brown adipose tissue in healthy adult humans: effects of cold exposure and adiposity. Diabetes 58 1526-1531. (https://doi.org/10.2337/db09-0530)

Sanchez-Garrido MA, Ruiz-Pino F, Manfredi-Lozano M, Leon S, GarciaGaliano D, Castano JP, Luque RM, Romero-Ruiz A, Castellano JM, Dieguez C, et al. 2014 Obesity-induced hypogonadism in the male: premature reproductive neuroendocrine senescence and contribution of Kiss1-mediated mechanisms. Endocrinology 155 1067-1079. (https://doi.org/10.1210/en.2013-1584)

Seminara SB, Messager S, Chatzidaki EE, Thresher RR, Acierno JS Jr, Shagoury JK, Bo-Abbas Y, Kuohung W, Schwinof KM, Hendrick AG, et al. 2003 The GPR54 gene as a regulator of puberty. New England Journal of Medicine 349 1614-1627. (https://doi.org/10.1056/ NEJMoa035322)
Shahab M, Mastronardi C, Seminara SB, Crowley WF, Ojeda SR \& Plant TM 2005 Increased hypothalamic GPR54 signaling: a potential mechanism for initiation of puberty in primates. PNAS $\mathbf{1 0 2}$ 2129-2134. (https://doi.org/10.1073/pnas.0409822102)

Skaznik-Wikiel ME, Swindle DC, Allshouse AA, Polotsky AJ \& McManaman JL 2016 High-fat diet causes subfertility and compromised ovarian function independent of obesity in mice. Biology of Reproduction 94 108. (https://doi.org/10.1095/ biolreprod.115.137414)

Smith JT 2013 Sex steroid regulation of kisspeptin circuits. Advances in Experimental Medicine and Biology 784 275-295. (https://doi. org/10.1007/978-1-4614-6199-9_13)

Smith JT, Cunningham MJ, Rissman EF, Clifton DK \& Steiner RA 2005a Regulation of Kiss1 gene expression in the brain of the female mouse. Endocrinology 146 3686-3692. (https://doi.org/10.1210/en.2005-0488)

Smith JT, Dungan HM, Stoll EA, Gottsch ML, Braun RE, Eacker SM, Clifton DK \& Steiner RA $2005 b$ Differential regulation of KiSS-1 mRNA expression by sex steroids in the brain of the male mouse. Endocrinology 146 2976-2984. (https://doi.org/10.1210/en.2005-0323)

Smith JT, Popa SM, Clifton DK, Hoffman GE \& Steiner RA 2006 Kiss 1 neurons in the forebrain as central processors for generating the preovulatory luteinizing hormone surge. Journal of Neuroscience $\mathbf{2 6}$ 6687-6694. (https://doi.org/10.1523/JNEUROSCI.1618-06.2006)

Smith JT, Li Q, Pereira A \& Clarke IJ 2009 Kisspeptin neurons in the ovine arcuate nucleus and preoptic area are involved in the preovulatory luteinizing hormone surge. Endocrinology 150 5530-5538. (https:// doi.org/10.1210/en.2009-0712)

Smith JT, Li Q, Yap KS, Shahab M, Roseweir AK, Millar RP \& Clarke IJ 2011 Kisspeptin is essential for the full preovulatory LH surge and stimulates GnRH release from the isolated ovine median eminence. Endocrinology 152 1001-1012. (https://doi.org/10.1210/en.2010-1225)

Song WJ, Mondal P, Wolfe A, Alonso LC, Stamateris R, Ong BW, Lim OC, Yang KS, Radovick S, Novaira HJ, et al. 2014 Glucagon regulates hepatic kisspeptin to impair insulin secretion. Cell Metabolism 19 667-681. (https://doi.org/10.1016/j.cmet.2014.03.005)

Stephens SB, Tolson KP, Rouse ML Jr, Poling MC, Hashimoto-Partyka MK, Mellon PL \& Kauffman AS 2015 Absent progesterone signaling in kisspeptin neurons disrupts the LH surge and impairs fertility in female mice. Endocrinology 156 3091-3097. (https://doi.org/10.1210/ en.2015-1300)

Teles MG, Bianco SD, Brito VN, Trarbach EB, Kuohung W, Xu S, Seminara SB, Mendonca BB, Kaiser UB \& Latronico AC 2008 A GPR54activating mutation in a patient with central precocious puberty. New England Journal of Medicine 358 709-715. (https://doi.org/10.1056/ NEJMoa073443)

Terao Y, Kumano S, Takatsu Y, Hattori M, Nishimura A, Ohtaki T \& Shintani Y 2004 Expression of KiSS-1, a metastasis suppressor gene, in trophoblast giant cells of the rat placenta. Biochimica et Biophysica Acta 1678 102-110. (https://doi.org/10.1016/j.bbaexp.2004.02.005)

Thomas GB, Mercer JE, Karalis T, Rao A, Cummins JT \& Clarke IJ 1990 Effect of restricted feeding on the concentrations of growth hormone $(\mathrm{GH})$, gonadotropins, and prolactin (PRL) in plasma, and on the amounts of messenger ribonucleic acid for $\mathrm{GH}$, gonadotropin subunits, and PRL in the pituitary glands of adult ovariectomized ewes. Endocrinology 126 1361-1367. (https://doi.org/10.1210/endo126-3-1361)

Thompson EL, Patterson M, Murphy KG, Smith KL, Dhillo WS, Todd JF, Ghatei MA \& Bloom SR 2004 Central and peripheral administration of kisspeptin-10 stimulates the hypothalamic-pituitary-gonadal axis. Journal of Neuroendocrinology 16 850-858. (https://doi.org/10.1111/ j.1365-2826.2004.01240.x)

Tolson KP, Garcia C, Yen S, Simonds S, Stefanidis A, Lawrence A, Smith JT \& Kauffman AS 2014 Impaired kisspeptin signaling decreases metabolism and promotes glucose intolerance and obesity. Journal of Clinical Investigation 124 3075-3079. (https://doi.org/10.1172/ JCI71075) 
Tolson KP, Garcia C, Delgado I, Marooki N \& Kauffman AS 2016 Metabolism and energy expenditure, but not feeding or glucose tolerance, are impaired in young Kiss1r KO female mice. Endocrinology 157 4192-4199. (https://doi.org/10.1210/en.2016-1501)

Tomikawa J, Uenoyama Y, Ozawa M, Fukanuma T, Takase K, Goto T, Abe H, Ieda N, Minabe S, Deura C, et al. 2012 Epigenetic regulation of Kiss1 gene expression mediating estrogen-positive feedback action in the mouse brain. PNAS 109 E1294-E1301. (https://doi.org/10.1073/ pnas.1114245109)

Tortoriello DV, McMinn J \& Chua SC 2004 Dietary-induced obesity and hypothalamic infertility in female DBA/2J mice. Endocrinology 145 1238-1247. (https://doi.org/10.1210/en.2003-1406)

Uenoyama Y, Inoue N, Pheng V, Homma T, Takase K, Yamada S, Ajiki K, Ichikawa M, Okamura H, Maeda KI, et al. 2011 Ultrastructural evidence of kisspeptin-gonadotrophin-releasing hormone ( $\mathrm{GnRH})$ interaction in the median eminence of female rats: implication of axo-axonal regulation of GnRH release. Journal of Neuroendocrinology 23 863-870. (https://doi.org/10.1111/j.1365-2826.2011.02199.x)

Vikman J \& Ahren B 2009 Inhibitory effect of kisspeptins on insulin secretion from isolated mouse islets. Diabetes, Obesity and Metabolism 11 (Supplement 4) 197-201. (https://doi.org/10.1111/j.14631326.2009.01116.x)

Wakabayashi Y, Nakada T, Murata K, Ohkura S, Mogi K, Navarro VM, Clifton DK, Mori Y, Tsukamura H, Maeda K, et al. 2010 Neurokinin $\mathrm{B}$ and dynorphin a in kisspeptin neurons of the arcuate nucleus participate in generation of periodic oscillation of neural activity driving pulsatile gonadotropin-releasing hormone secretion in the goat. Journal of Neuroscience 30 3124-3132. (https://doi.org/10.1523/ JNEUROSCI.5848-09.2010)
Wakabayashi Y, Yamamura T, Sakamoto K, Mori Y \& Okamura H 2013 Electrophysiological and morphological evidence for synchronized GnRH pulse generator activity among Kisspeptin/neurokinin B/ dynorphin A (KNDy) neurons in goats. Journal of Reproduction and Development 59 40-48. (https://doi.org/10.1262/jrd.2013-060)

Walters KA, Edwards MC, Tesic D, Caldwell ASL, Jimenez M, Smith JT \& Handelsman DJ 2018 The role of central androgen receptor actions in regulating the hypothalamic-pituitary-ovarian axis. Neuroendocrinology 106 389-400. (https://doi.org/10.1159/000487762)

Yamamura T, Wakabayashi Y, Sakamoto K, Matsui H, Kusaka M, Tanaka T, Ohkura S \& Okamura H 2014 The effects of chronic subcutaneous administration of an investigational kisspeptin analog, TAK-683, on gonadotropin-releasing hormone pulse generator activity in goats. Neuroendocrinology 100 250-264. (https://doi. org/10.1159/000369819)

Yamamura T, Wakabayashi Y, Ohkura S, Navarro VM \& Okamura H 2015 Effects of intravenous administration of neurokinin receptor subtype-selective agonists on gonadotropin-releasing hormone pulse generator activity and luteinizing hormone secretion in goats. Journal of Reproduction and Development 61 20-29. (https://doi.org/10.1262/ jrd.2014-109)

Yap CC, Wharfe MD, Mark PJ, Waddell BJ \& Smith JT 2016 Diurnal regulation of hypothalamic kisspeptin is disrupted during mouse pregnancy. Journal of Endocrinology 229 307-318. (https://doi. org/10.1530/JOE-16-0086)

Yeo SH, Kyle V, Morris PG, Jackman S, Sinnett-Smith LC, Schacker M, Chen C \& Colledge WH 2016 Visualisation of Kiss1 neurone distribution using a Kiss1-CRE transgenic mouse. Journal of Neuroendocrinology 28. (https://doi.org/10.1111/jne.12435)

Received in final form 10 June 2018

Accepted 13 June 2018 (c) 2018 Society for Endocrinology Published by Bioscientifica Ltd. Printed in Great Britain 